\title{
JÄYKKIEN SAVIEN PINTAKERROKSEN LAADUSTA
}

\author{
Reijo Heinonen \\ Yliopiston maanviljelyskemian laitos, Helsinki
}

Saapunut 3. 1. 1962

AARNion mukaan jäykkä savi (eli aitosavi) on vallitseva viljelysmaatyyppi "koko siinä osassa maatamme, jota pohjoisessa rajoittaa Salpausselkä ja sen jatkoksi ajateltu kaari, joka Lahden seuduilta jatkuisi luodetta kohti, . . . aina lähełle Kokemäenjoen suupuolta (1, s. 141). JuUSELA ja WÄRE (5) ovat sittemmin tehneet edustavalla aineistolla kuivatustilatutkimukseen liittyvän peltojen maalajisuhteiden selvityksen, joka osoitti, että aitosavea oli Turun maanviljelysinsinööripiirissä 16.5 \%, Helsingin piirissä $11.2 \%$ ja Kymen piirissä $4.0 \%$ peltoalasta, siis huomattavasti vähemmän kuin aikaisemmin oli otaksuttu.

Kirjoittaja on omien havaintojensa perusteella joutunut päättelemään, että nämäkin prosenttiluvut, jotka ovat ilmeisesti oikeaanosuvia kuivatusteknillisiin tarkoituksiin, ovat viljelyteknillisiä tarkasteluja silmälläpitäen vielä liian korkeita. Onhan niiden perustana kunkin peltolohkon alempaa puolikasta edustavan pohjamaanäytteen maalaji (5, s. 16), ja tulos ei siten voi antaa aivan oikeaa kuvaa koko peltoalasta eikä varsinkaan sen multakerroksesta, jonka savespitoisuus näyttää olevan usein pienempi kuin pohjamaan $(3,4)$.

Kun maalajin viljelyominaisuudet riippuvat ratkaisevimmin multakerroksesta, ja näytti olevan aihetta tarkistaa erikoisesti aitosaven ominaisuuksista ja levinneisyydestä vallinneita käsityksiä (3), kirjoittaja kääntyi em. kuivatustilatutkimuksen suorittajien puoleen pyytäen saada analysoida yksityiskohtaisemmin heidän aineistoaan. Tohtorit JUUSELA ja WÄRE luovuttivatkin tarpeelliset osat keräämästään arvokkaasta maanäyteaineistosta kirjoittajan käytettäväksi. ${ }^{1}$ )

Tulokset osoittivat, että aitosavialueen multakerros on yleisesti maalajiltaan kevyempää kuin jankko. Aineisto tarjosi myös tilaisuuden tiettyjen maalajiominaisuuksien keskinäisten riippuvuussuhteiden tarkasteluun.

1) Tämä ystävällinen teko ansaitsee kirjoittajan lämpimän kiitoksen. 


\section{Aineisto ja tutkimusmenetelmät}

JUUSELAn ja WÄREen otantatutkimukseen (5) sisältyi yksi lohko kutakin 1000 peltohehtaaria kohti. Tutkittavalta lohkolta otettiin aina maanäytteet kahdesta kohdasta, joista toinen (a) edusti lohkon ylempää ja toinen (b) alempaa puolikasta. Kummastakin kohdasta otettiin näyte multakerroksesta (al ja b1) ja jankosta $10 \mathrm{~cm}$ sen alapuolelta (a2 ja b2). Mekaaninen maa-analyysi tehtiin vain b2-näytteistä,

Käsillä olevaa tutkimusta varten kirjoittaja poimi aineistosta ne Helsingin ja Turun maanviljelysinsinööripiirien peltolohkot, joissa b2-näytteen savespitoisuus oli vähintään $60 \%$, ts. jankon maalaji lohkon alapäässä aitosavea. Tällaisia pisteitä oli primääriaineistossa kaikkiaan $121 \mathrm{kpl}$, mutta osa näytteistä oli hukkunut tai kulunut aikaisemmissa analyyseissä niin vähiin, ettei mekaanista maa-analyysia voitu enää tehdä. Tilastolliseen käsittelyyn otetut aukottomat tulossarjat saatiin siten vain 82 peltolohkosta. Tämä määrä on kuitenkin aineiston edustavuutta silmälläpitäen riittävä, sillä näytteiden puuttuminen on ilmeisesti täysin sattumanvaraista.

Mekaaniset maa-analyysit tehtiin kirjoittajan täsmentämällä areometrimenetelmällä (2). Kaikki näytteet käsiteltiin $\mathrm{H}_{2} \mathrm{O}_{2}$ :lla orgaanisen aineen poistamiseksi ja sen jälkeen pääosa liukoisista suoloista dekantoitiin pois. Hiekka ja karkea hieta määritettiin seulomalla liete areometrimittausten jälkeen. Hienon hiedan määrä saadaan normaalisti areometrillä, mutta tietyissä tapauksissa tulos tarkastettiin sifonointimenetelmällä. Näin varmistettuja mekaanisen analyysin tuloksia voidaan pitää käytännöllisesti katsoen yhtä luotettavina kuin pipettimenetelmällä saatuja.

b2-näytteiden osalta tuloksia voitiin verrata kuivatustilatutkimuksen (5) yhteydessä tehtyihin areometrianalyyseihin. Savespitoisuuden keskiarvo osoittautui kummassakin tapauksessa miltei tarkalleen samaksi $(70.24$ ja $70.10 \%$ ) ja $3 / 4$ yksityistapausten poikkeamista oli alle $5 \%$-yksikköä. Yhtäpitävyyttä voidaan pitää tyydyttävänä, kun otetaan huomioon, että aikaisemmat analyysit oli tehty nopeammalla menetelmällä ilman $\mathrm{H}_{2} \mathrm{O}_{2}$-käsittelyä ja muita tarkistuksia. Tässä tutkimuksessa on kauttaaltaan nojauduttu kirjoittajan analyyseihin ja siitä johtuu, että esim. piirroksessa 1 muutamien b2-näytteiden savespitoisuus on vähän alle $60 \%$, vaikka sellaisia ei pitänyt sisältyä aineistoon.

Multanäytteiden orgaaninen hiili määritettiin Walkley-Black-märkäpoltolla ja tulokset korjattiin vertailumaan avulla vastaamaan täydellisellä poltolla saatavia orgaanisen hiilen totaalimääriä.

\section{Tulosten tarkastelua}

Peltolohkojen ylä- ja alapään vertailu

Peltolohkojen alapään jankon maalajin mukaan lukien Turun ja Helsingin maanviljelysinsinööripiirien yhteisestä peltoalasta lienee aitosavea varovasti arvioiden n. $15 \%$. JUUSELAn ja WäREen mukaan punnituksi keskiarvoksi saadaan tosin vain $13.7 \%$, mutta kirjoittajat pitävät itse tätä arviota liian alhaisena, koska osa aitosavista on ilmeisesti tullut laskettua liejusaviin (5, s. 25). 


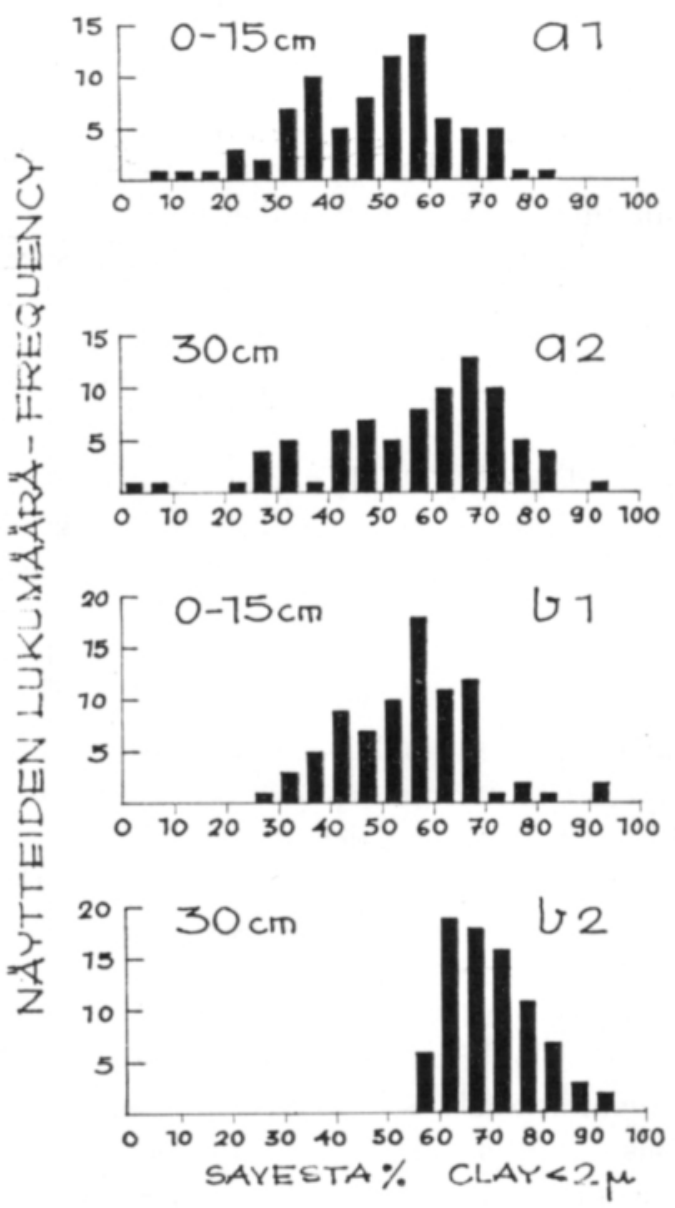

Piirros 1. 82 peltolohkoa käsittävän aineistọ jakautuminen maan savespitoisuuden mukaan lohkon ylemmässä (a) ja alemmassa (b) puolikkaassa multakerroksessa (1) ja jankossa (2).

Fig. 1. Distribution of soils according to the clay content in the upper $(a)$ and lower $(b)$ parts of the fields, in the topsoil (1) and the subsoil (2).

Kun tätä arviota lähdetään tarkistamaan koko peltoalaa silmälläpitäen, voidaan piirroksia 1 ja 2 tarkastelemalla todeta, että peltolohkon yläpään maalaji on sekä multakerroksessa että jankossa yleensä kevyempi kuin alapään, joskin hajonta on hyvin suuri. Jankon keskimääräinen savespitoisuus oli tässä aineistossa alapäässä $70.1 \%$ ja yläpäässä $56.8 \%$. Multakerroksen osalta vastaavat luvut olivat 55.2 ja $48.6 \%$. Piirroksen 1 mukaan a2-näytteistä on aitosavea (yli $60 \%$ savesta) vain $52 \%$.

Toisaalta on syytä kiinnittää huomiota siihen, että n. 1/4:ssa tapauksista yläpään savespitoisuus on suurempi kuin alapään. Tietty määrä peltolohkojen yläpäissä esiintyvää aitosavea on siten jäänyt pois tutkimusaineistosta siitä syystä, että maan savespitoisuus on ollut lohkon alapäässä alle $60 \%$. Aineiston jakautumia tarkas- 
telemalla voidaan arvioida, että lohkojen ylemmissä puolikkaissa on aitosavea $52 \%$ :n asemesta kaikkiaan n. $60-65 \%$ alempien puolikkaiden aitosaven alasta. Tästä saataisiin aitosaven osuudeksi tutkimusalueen koko peltoalasta $15 \%$ :n asemesta $12 \%$, jankon maalajin mukaan laskien.

\section{Multakerroksen ja jankon vertailu}

Piirroksista 1 ja 3 ilmenee, että jäykemmissä savissa multakerroksen savespitoisuus on yleisesti pienempi kuin jankon. Samaa eroa ei näytä ilmenevän $40 \%$ :n savespitoisuuden alapuolella, mutta aineisto on tältä osin liian suppea päätelmien tekoon. Suhde multakerroksen ja jankon savespitoisuuden välillä näyttää olevan samanlainen pellon ylä- ja alapäässä, minkä vuoksi koko aineistolle laskettiin yhteinen regressiosuora piirrokseen 3. Tapaukset, joissa multakerros on aitosavea ja jankko jotakin kevyempää maalajia, ovat ilmeisesti harvinaisia, sillä tähän aineistoon sisältyi vain yksi sellainen tapaus.

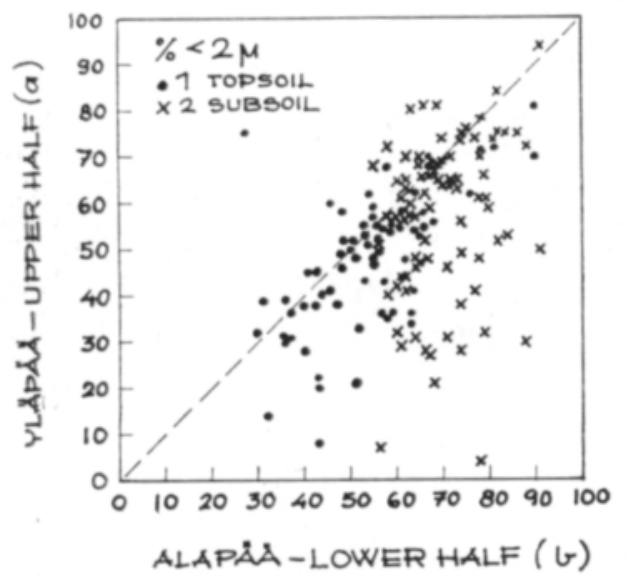

Piirros 2. Peltolohkojen ylempien ja alempien puolikkaiden savespitoisuuksien suhde. Viitteenä pilkkuviiva $45^{\circ}$ :ssa.

Fig. 2. Ratio between the clay contents of the soils in the upper and lower parts of the fields. $45^{\circ}$ line as a reference.

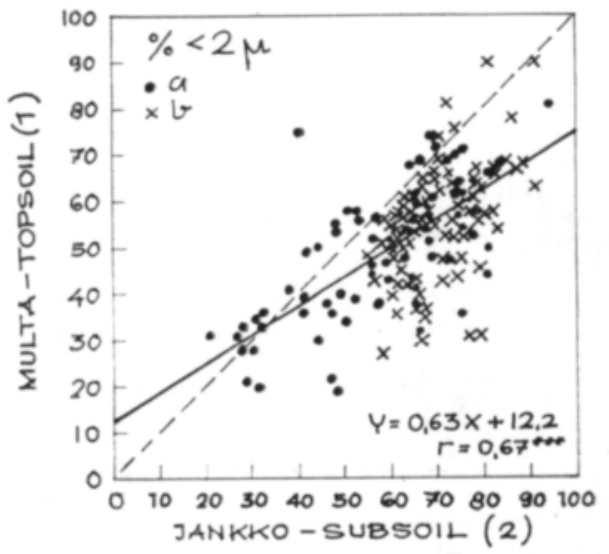

Piirros 3. Multakerroksen ja jankon savespitoisuuksien suhde. a- ja b-pisteille on laskettu yhteinen regressiosuora, minkä ohella on viitteennä pilkkuviiva $45^{\circ}$ :ssa.

Fig. 3. Ratio between the clay contents of the topsoil and subsoil. The regression line has been calculated for the combined values of the $a$ and $b$ samples. $45^{\circ}$ line as a reference.

Piirroksen 4 mukaan aitosavipohjaisten peltojen multakerros jakautuu eri maalajeihin seuraavasti: aitosavea $40 \%$, hiesusavea $29 \%$, hiuesavea $23 \%$, hietasavea $7 \%$, kevyempää maalajia $1 \%$. Jos oletetaan, että aitosavi on jankon maalajina $12 \%$ :ssa tutkimusalueen koko peltoalasta, se olisi multakerroksen maalajina $5 \%$ :ssa. Tästäkin on suurin osa lähellä aitosaven alarajaa, yli $70 \%$ :n savespitoisuudet ovat multakerroksessa verraten harvinaisia. 


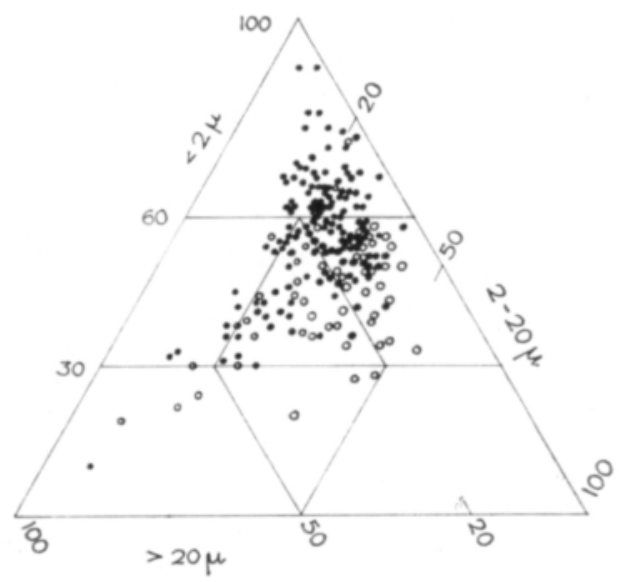

Piirros 4. Savimaiden multakerroksen raekoostumus. Avoin rengas = jankossa savesta $30-60 \%$. Täysi rengas = jankossa savesta yli $60 \%$.

Fig. 4. Topsoil texture in clay soils. Open circle = clay content in subsoil $30-60 \%$. Solid circle $=$ clay content in the subsoil over $60 \%$.

Orgaanisen aineksen määrä ja sen riippuvuus maalajista

Piirroksessa 5 on esitetty näytteiden jakautuminen multakerroksen hiilipitoisuuden mukaan. Tällöin on otettu mukaan kaikki tutkittavaksi saadut al- ja blnäytteet siitä aineistosta, jossa jankon maalaji on lohkon alapäässä aitosavea. Yläja alapään jakautumiskuviot olivat huipun alueella jokseenkin samanlaiset, minkä vuoksi ne yhdistettiin. Orgaanisen hiilen totaalimäärän tyyppiarvoksi (moodi) saatiin kummassakin tapauksessa $3.2 \%$ ja jos se muunnetaan orgaaniseksi aineeksi

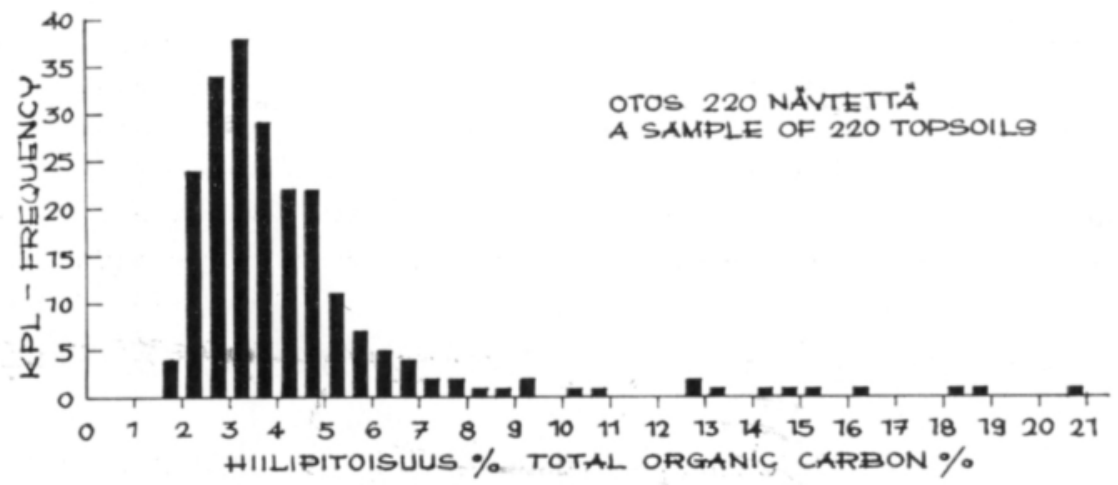

Piirros 5. Multanäytteiden jakautuminen orgaanisen hillen pitoisuuden perusteella. Piirrokseen on otettu myös sellaiset edustavan aineiston 1-näytteet, joita ei sarjojen vajavuuden takia voitu sisällyttāä muihin tarkasteluihin.

Fig. 5. Distribution of the topsoils according to the organic carbon content. All available a1 and b1 samples of the representative material. 
kertoimella 1.9, saadaan tulokseksi $6.1 \%$. Aritmeettinen keskiarvo sen sijaan oli alapäässä hieman suurempi, $4.7 \%$ hiiltä, yläpään vastaavan arvon ollessa $4.3 \%$. Tämä johtuu lähinnä siitä, että huippukohdan ulkopuolella alapäässä esiintyi suuria arvoja enemmän ja pieniä arvoja vähemmän kuin yläpäässä.

Tarkasteltaessa hiilipitoisuuden suhdetta mullan ja jankon savespitoisuuteen pellon ylä- ja alapäässä ilmeni, että yläpäässä mullan hiili- ja savespitoisuuksien välillä on melko voimakas positiivinen korrelaatio $\left(r=0.47^{* * *}\right.$, piirros 6$)$. Sen sijaan hiilipitoisuuden korrelaatio jankon savespitoisuuden kanssa oli hyvin heikko $(\mathrm{r}=$ $0.11)$. Edellä mainittujen kertoimien erotus on tilastollisesti merkitsevä $\left(\mathrm{t}=2.6^{*}\right)$. Tämä tulos voitaneen selittää siten, että saves hidastaa orgaanisen aineksen hajau-

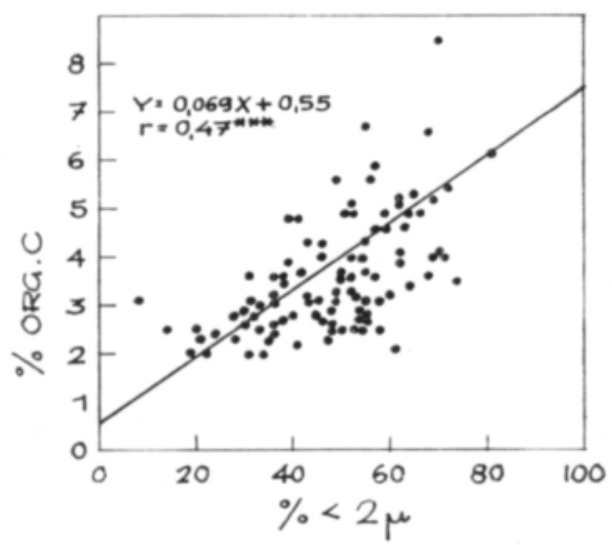

Piirros 6. Mullan hiili- ja savespitoisuuksien suhde al-näytteissä.

Fig. 6. Ratio between the carbon and clay contents in the a1 samples.

tumista maassa, jolloin (viljelyjärjestelmän ollessa suunnilleen samanlainen) orgaanisen aineksen muodostuksen ja hajoituksen välinen tasapaino saavutetaan sitä korkeammassa hiilipitoisuudessa, mitä korkeampi on savespitoisuus (ks. 6, s. 289).

Pellon alapäässä korrelaatiokerroin mullan hiili- ja savespitoisuuden välillä oli vain 0.15 , mikä on merkitsevästi pienempi kuin yläpään vastaava arvo $0.47 * * *$. Korrelaatio jankon savespitoisuuteen puuttui täysin. Hiilipitoisuuden riippumattomuus maalajista pellon alapäässä lienee tulkittava siten, että entisten kuivatussuhteiden ja turvekerrosten vaikutus peittää täällä maalajin vaikutuksen.

\section{Yhteenveto}

Aikaisempien tutkimusten perusteella voidaan olettaa, että aitosaven osuus Helsingin ja Turun maanviljelysinsinööripiirien peltoalasta on n. $15 \%$, jos lähtökohtana on jankon maalaji kunkin peltolohkon alemmassa puolikkaassa. Käsilläolevassa työssä on tarkistettu tätä arviota analysoimalla edustavasta näyteaineistosta myös peltolohkon ylempää puolikasta ja multakerrosta edustavat näytteet, 
joiden tekstuuri on yleensä kevyempi kuin jankon. Siten päädyttiin arvioon, että aitosavi on jankon maalajina $12 \%$ :ssa tutkimusalueen koko peltoalasta. Multakerroksessa aitosaven osuus olisi vain $5 \%$.

Orgaanisen aineksen määrä oli positiivisessa korrelaatiossa multakerroksen savespitoisuuden kanssa peltolohkojen ylemmissä mutta ei alemmissa puolikkaissa. Humuspitoisuuden tyyppiarvoksi saatiin koko aineistossa $6.1 \%$.

\section{KIR JALLISUUTTA}

(1) Aarnıo, B. 1939. Mineralogian, geologian ja maaperäopin oppikirja. 163 s. ja kartta. PorvooHelsinki.

(2) Heinonen, R. 1958. Areometrimenetelmän soveltamisesta Suomen maalajien mekaaniseen analyysiin. Summary: The hydrometer method of mechanical soil analysis; an application to Finnish soils. Maa- ja vesirak. 3: 7-19.

(3) - 1961. Soil productivity in the textural range from clay loam to very heavy clay. Selostus: Maan tuottokyvystä hietasavi-aitosavialueella. Acta agr. fenn. 99, 2: 1-22.

(4) - \& \& Tähtinen, H. 1961. Soil composition and seed-bed preparation in relation to yields: analysis of a tillage experiment on Anjala clay. Selostus: Maan koostumuksen ja kevätmuokkaustavan vaikutus satoon: Anjalan savimaalla tehdyn muokkauskokeen analyysi. Ibid. 97, 3: 1-15.

(5) JuUsela, T. \& WÄre, M. 1956. Suomen peltojen kuivatustila. Draining condition of the cultivated fields in Finland. Maa- ja vesitekn. julk. 8: 1-90.

(6) Russell, E..W. 1961. Soil conditions and plant growth. 9. painos. 688 s. London.

SUMMARY:

ON THE CHARACTERISTICS OF TOPSOILS OVERLYING HEAVY CLAYS

Reijo HeINONEN

Department of Agricultural Chemistry, University of Helsinki

When the importance of the texture of the topsoil became apparent $(3,4)$, it was recognised that more reliable information was necessary about the distribution of topsoils among the different textural classes, and especially about the occurrence of very heavy clay as a topsoil. Practically all earlier estimates are based on mechanical analyses of subsoils, as it has been assumed that there is not much textural difference between the subsoil and the topsoil, an assumption now proved to be wrong.

The author made use of a statistically representative sample of the soils of the Helsinki and Turku hydrotechnical districts (S.W. Finland), made available by JuUsELA and WÃre (5). One field per 1000 hectares of cultivated land was sampled, and from each field four samples were taken as follows:

$$
\text { upper half of the field }\left\{\begin{array}{l}
\text { al topsoil } \\
\text { a2 subsoil } \sim 30 \mathrm{~cm} \text { depth }
\end{array}\right.
$$

From the material the author picked all the fields where the clay content of the b2 sample had been shown to exceed $60 \%(5)$. This made a total of 121 fields, but complete series of four samples were only available from 82 fields. A random omission of this extent does not, however; significantly reduce the representativeness of the material. 
For the present paper the author made a mechanical soil analysis of all samples by an accurate hydrometer method including $\mathrm{H}_{2} \mathrm{O}_{2}$ treatment (2), and an organic carbon determination of the topsoil samples. From the results, presented in Figs. 1 to 6 , the following facts emerge:

The clay content was generally smaller in the upper part of the field than in the lower part, and smaller in the topsoil than in the subsoil. From the earlier analyses of the b2 samples (5), the percentage of very heavy clay (over $60 \%<2 \mu$ ) may be estimated as $15 \%$ of the cultivated land of the studied area (the distinction from the post-glacial muddy clay is not quite clear). Now, after all samples have been analysed, the estimate drops to $12 \%$ if subsoils are considered, and to $5 \%$ if topsoils are considered.

The modal class of the total organic carbon content was $3.0-3.4 \%$ (Fig. 5). The carbon content was positively correlated with the clay content of the topsoil (but not with that of the subsoil) in the upper parts of the fields (Fig. 6). This is in line with the theory that the higher the clay content, the slower is the decomposition of the organic matter. No such correlation was observed in the lower parts of the. fields, where the original drainage conditions may decide the organic matter content. 